\title{
Transition to Second Parity: Role of Employment and Household Decision-Making Autonomy in Bangladesh
}

\author{
Ahbab Mohammad Fazle Rabbi* \\ Department of Applied Science Bangladesh University of Textiles, Dhaka, Bangladesh \\ *Corresponding author: amfrabbi@hotmail.com
}

Received April 22, 2013; Revised May 04, 2013; Accepted June 15, 2013

\begin{abstract}
This work focuses on Bangladesh, a country where population is one of the major problem but fertility rates decline in the last few decades sharply. The progression from first to second birth is a crucial component in fertility change; for this reason, the study aims at analyzing the second-birth intensities of Bangladesh. Proportional hazards models have been applied to the 2007 Bangladesh Demographic and Health Survey from the view of mother's employment status and household decision-making autonomy. The obtained results suggest, for few factors like mothers education level, employment status and mass media exposure status, the parity transition time varied between non-empowered, moderately empowered and highly empowered mothers while determinants of birth interval suggest, employment status is a significant differential for timing of second parity.
\end{abstract}

Keywords: fertility, empowerment, Bangladesh

Cite This Article: Fazle Rabbi, Ahbab Mohammad, "Transition to Second Parity: Role of Employment and Household Decision-Making Autonomy in Bangladesh.” American Journal of Public Health Research 1, no. 6 (2013): 140-145. doi: 10.12691/ajphr-1-6-3.

\section{Introduction}

Since the late 1990s, the fertility rates of Bangladesh falls sharply, where rates have fallen to 3.3 or lower in 2004 and recent years in recent years it reached to 2.7 [1]. As has been shown by an extensive body of literature, this general trend has resulted from changes in preferences for small families, women education, employment rates, effects of mass media and so on. If the first phase of the fertility transition has been generally marked by an increase in the age at marriage, in the long run the diffusion of the smaller family will play a major role in countries of advanced transition, such as Egypt [2]. The progression from first to second birth, thus, is a crucial component in fertility change, since the reduction especially of higher-order births maintains the fertility decline.

As transition to second parity is one of the beginning steps of boost fertility, wide range of research is available on it $[3,4,5]$. Transition to second birth had been examined for few selected European countries [6]. Findings suggests that delays in second births are significant in countries with high unemployment and both among women who are unemployed, particularly the least educated, and those who have temporary jobs. In Spain, a high jobless rate and the widespread use of limited-duration contracts are found to be correlated with a substantial postponement of second births. Furthermore, unemployment may alter the childbearing plans not only of those directly affected by it, but also of those to whom it constitutes a threat. For recent years, has found the effect of unemployment at the municipality level in Norway to be more important than individual unemployment shocks for higher order birth rates [7]. The reduction in the opportunity cost of time devoted to children (forgone wages) associated with an unemployment spell is expected to boost fertility [8]. Another study revealed that women education and employment are likely factors that encourage couples to delay marriage and use modern family planning methods which play vital role in reducing marital fertility in Oman [9]. It is also observed that, if the negative income effect from reduced work earnings is sufficiently large, unemployment may lead to increase in fertility level. The point in life when unemployment episodes occur, and how long they (are expected to) last; are thus an important fact for change in fertility level. Furthermore this employment status bring another subsequent question- were they empowered or not in their daily life; in terms of decisionmaking in spending money, household decision, movement. The terms women's empowerment and autonomy have been used interchangeably to denote women's independence at various levels. It have stated by previous researchers that empowerment is the ability of individuals to gain control socially, politically, economically, and psychologically through (a) access to information, knowledge, and skills; (b) decision-making; and (c) individual self-efficacy, community participation, and perceived control [10]. There is a common assumption that education leads to autonomy, which lets women stand up to their husbands and/or provides them a forum for them to learn about fertility control and make effective use of health care system [11]. Autonomy has been defined as the ability- technical, social and psychological- to obtain information and to use it as the 
basis for making decisions about one's private concerns and those intimates [12].

However, the complexities of this relationship are poorly understood, especially during fertility transitions. There are few previous studies on women's empowerment and reproductive outcomes. Previous studies demonstrates that women's empowerment is associated with contraceptive use $[13,14,15,16]$, lower fertility $[17,18]$, and longer birth intervals [19]. It have been concealed that weak position of women in economic spheres of Pakistan, inhibits them to make choices about family size and family planning use [20]. Some researchers have suggested that women's empowerment is a key pathway through which education influences fertility [11]. Another research was designed to explore the relationship between a fertility decline and the empowerment of women, particularly to gender equity within families in rural area of Kilimanjaro Region, Tanzania [21]. Findings suggest that in this population age at first birth increased and the progression from having one child to the next child declined related to the status of women, particularly, free partner choice, women's education and wealth of the family. Another recent work was compiled on Pakistan which discovered that, woman's control on household monthly expenditures is directly associated with the contraceptive use and inversely related with family size [20]. This study further acknowledged that women with a certain financial control on monthly household expenditures significantly have a boost on contraceptive use and in reducing family size.

Thus most of the previous studies shown that women's empowerment is associated with contraceptive use, lower fertility, and longer birth intervals. Yet little is known about the association of women's empowerment with fertility desires in developing countries where overall fertility levels started to fall sharply. This study tries to fill this gap, exploring whether women's employment status and empowerment affects the fertility levels, in particular their transition to second parity. This study tried to explain the parity transition from first to second child for Bangladesh, in terms of women employment status and empowerment level.

\section{Data and Analysis Procedure}

The data for this study is obtained from Bangladesh Demographic and Health Survey (BDHS) 2007 which is a nationally representative survey. This survey was conducted under the authority of the National Institute for Population, Research and Training (NIPORT) of the Ministry of Health and Welfare, Bangladesh and funded by USAID. Stratified Multi-stage Cluster Sampling design was used to collect data. BDHS 2007 data includes 10996 women of childbearing age of all six divisions in the country.

To study the parity transition scenario for second birth (timing of second birth), dependent variable is months to a birth from the first birth. From birth history data birth intervals are computed by subtracting date of first birth from date of birth of index child. Cox proportional hazards model is used in this study; as dependent variable of the current study is time dependent and it satisfied the proportionality assumptions. Estimated hazard ratios from
Cox proportional hazard models present the ratio of odds for terminating second birth interval for each category of the independent variables compare to that of the reference group. Besides employment status, important factors of demographic, socio-economic and healthcare facilities have been identified as explanatory variables on the basis of chi-square test and from the previous studies. They are mother's age at first marriage, previous birth interval, gender of first child, region, place of residence (urban/rural), contraception status, mother's education and exposure status to mass media.

It is hard to define empowerment level by using a single index value. From previous studies, empowerment levels have to be measured using three different viewseconomic decision-making autonomy, household decision-making autonomy and freedom of movement autonomy [16]. According to previous studies the established indicators of economic decision-making autonomy are- 'Who decides how to spend money'; 'Final say on large household purchases' and 'Final say on making household purchases for daily needs'. Indicators of household decision-making autonomy are- 'Final say on own health care'; 'Final say on child health care'; 'Justification of wife beating' and 'Discussion about family planning with partner'. Indicators of freedom of movement autonomy are, 'Final say on visits to family or relatives' and 'Goes to a health centre or hospital alone' [16]. In bivariate analysis, only household decisionmaking autonomy showed significant relation with timing of second birth among these three dimensions. Thus, only household decision-making autonomy is considered in the present study and 'Justification of wife beating' is omitted to indicate this autonomy due to problem of severe missing values. Those who have no say on any of the indicator of Household decision making autonomy are considered as 'not empowered'; those who have say in all of the indicators are considered as 'empowered' and rests are considered as 'moderately empowered'.

\section{Results}

The percentage distributions and summary statistics for all of the empowerment level for three dimensions and employment level is showed in Table 1. From BDHS 2007, only $32.7 \%$ mothers were employed. According to economic decision-making autonomy, 62.5\% were highly empowered; according to household decision-making autonomy, 25.9\% mothers were highly empowered and according to freedom of movement autonomy, 51\% were highly empowered. Employed mothers have higher second birth intervals then unemployed mothers (Table 1). The findings also indicate that, length of second birth intervals increase with level of empowerment; highly empowered mothers have higher second birth intervals for all three indicators than not-empowered mothers (Table 1).

Cox Proportional Hazards models have been applied to estimate the effects of employment status on second birth interval. Table 2 presents the estimated hazards models for transition to second birth for each category of employment status. When analyzing these results, it should be noted that, these estimated coefficients cannot be given as a direct causal interpretation, since they may be confounded by unobserved factors. Women who are unemployed, less 
likely to have a child than economically active women, vice versa is also possible in context of Bangladesh. It is because employed mothers may be less able to trade off work for further offspring. Similarly, highly educated mothers also intend to have less number of parity [17]. Employed mothers, got married at their early life, are found to have larger second birth interval than their unemployed counterpart. In case of marital age 25 or more, employed mother found to have shorter birth interval compare to unemployed mother. Previous birth interval played significant role in case of unemployed mothers, which is found to be insignificant in case of employed mother.

Table 1. Percentage distribution and summary distribution second birth interval by employment status and dimensions of women empowerment (BDHS-2007)

\begin{tabular}{|c|c|c|c|c|}
\hline $\begin{array}{l}\text { Dimensions of } \\
\text { Empowerment }\end{array}$ & Indicators & Percentage & $\begin{array}{c}\text { Mean } \\
\text { (months) }\end{array}$ & $\begin{array}{l}\text { Median } \\
\text { (months) }\end{array}$ \\
\hline \multirow{2}{*}{$\begin{array}{c}\text { Employment } \\
\text { Status }\end{array}$} & Unemployed & 67.3 & 42.51 & 33.00 \\
\hline & Employed & 32.7 & 49.60 & 37.00 \\
\hline \multirow{3}{*}{$\begin{array}{c}\text { Economic } \\
\text { decision- } \\
\text { making } \\
\text { autonomy }\end{array}$} & $\begin{array}{c}\text { Non- } \\
\text { empowered }\end{array}$ & 4.6 & 40.59 & 35.50 \\
\hline & $\begin{array}{l}\text { Moderately } \\
\text { empowered }\end{array}$ & 32.9 & 45.17 & 36.00 \\
\hline & $\begin{array}{c}\text { Highly } \\
\text { empowered }\end{array}$ & 62.5 & 47.99 & 38.00 \\
\hline \multirow{3}{*}{$\begin{array}{c}\text { Household } \\
\text { decision- } \\
\text { making } \\
\text { autonomy }\end{array}$} & $\begin{array}{c}\text { Non- } \\
\text { empowered }\end{array}$ & 10.1 & 37.12 & 30.00 \\
\hline & $\begin{array}{l}\text { Moderately } \\
\text { empowered }\end{array}$ & 64.0 & 42.93 & 35.00 \\
\hline & $\begin{array}{c}\text { Highly } \\
\text { empowered }\end{array}$ & 25.9 & 43.18 & 36.00 \\
\hline \multirow{3}{*}{$\begin{array}{c}\text { Freedom of } \\
\text { movement } \\
\text { autonomy }\end{array}$} & $\begin{array}{c}\text { Non- } \\
\text { empowered }\end{array}$ & 11.4 & 38.11 & 30.00 \\
\hline & $\begin{array}{l}\text { Moderately } \\
\text { empowered }\end{array}$ & 37.6 & 43.27 & 33.00 \\
\hline & $\begin{array}{c}\text { Highly } \\
\text { empowered }\end{array}$ & 51.0 & 47.90 & 36.00 \\
\hline
\end{tabular}

Gender of first child plays significant role on duration of second birth interval for both unemployed and employed mother in this study. Gender preference is still present according to hazard ratios, chance of terminating second birth intervals increase 14.5 percent for unemployed mothers (hazard ratio 1.145) while employed mother have 9.8 percent shorter birth interval if the first child was female (reference group was son). According to previous studies, old and traditional belief about expected social security from son, cause these sorts of parity transition [22]. Like the previous studies, current study also reveals that contraceptive user mothers have shorter birth interval compare to non-users, in case of unemployed mothers. For unemployed mothers modern method users have 51.4 percent shorter birth interval compare to non-users. The possible reason is, those who are ever users are young newly married and want to keep their family size small. However, at young age they are more fertile, so birth interval may be shorter. Similar results were obtained in the previous study [23]. Regional and residence factor are present; mothers of Khulna division are found to have larger birth interval compared to all other division. Similar result was obtained for Norway [7]. Rural resides mothers have shorter second birth interval compare to urban mothers; unemployed mothers have 2.9 percent while employed mothers have 7.3 percent shorter birth interval than urban mothers. For employed mothers this result is kind of unusual, one of the possible reasons may be relaxed job structure in rural areas, which accept mothers to have second parity in shorter duration and ability to take proper care. However, this assumption needs further investigation after controlling other socio-economic relevant factors. Wealth index is another important determinant for parity transition. Here comes the effect of employment status once again; employed mothers always intend to have larger birth interval whether the socio-economic status is.

Table 2. Hazards Models of the risk of second birth interval by employment status of mothers; BDHS-2007

\begin{tabular}{|c|c|c|}
\hline $\begin{array}{l}\text { Demographic and socio- } \\
\text { economic characteristics }\end{array}$ & Unemployed & Employed \\
\hline $\begin{array}{c}\text { Mother's age at first } \\
\text { marriage } \\
\leq 15 \text { (ref) } \\
16-19 \\
20-24 \\
\geq 25\end{array}$ & $\begin{array}{c}0.940^{*} \\
0.776^{* * *} \\
0.711\end{array}$ & $\begin{array}{c}0.838 * * * \\
0.766^{* *} \\
1.083\end{array}$ \\
\hline $\begin{array}{c}\text { Previous birth interval } \\
\leq 12 \text { (ref) } \\
13-24 \\
25-36 \\
\geq 37\end{array}$ & $\begin{array}{c}1.012 \\
0.999 \\
0.879 * *\end{array}$ & $\begin{array}{l}1.033 \\
1.095 \\
0.933\end{array}$ \\
\hline $\begin{array}{c}\text { Gender of } 1^{\text {st }} \text { child } \\
\text { Male (ref) } \\
\text { Female }\end{array}$ & $1.145^{* * *}$ & $1.098 * *$ \\
\hline $\begin{array}{c}\text { Division } \\
\text { Barishal (ref) } \\
\text { Chittagong } \\
\text { Dhaka } \\
\text { Khulna } \\
\text { Rajshahi } \\
\text { Sylhet }\end{array}$ & $\begin{array}{l}1.294 * * * \\
1.019 \\
0.816^{* * *} \\
0.867 * * * \\
1.409 * * *\end{array}$ & $\begin{array}{c}1.319 * * * \\
1.162 * * \\
0.853^{* *} \\
0.910 \\
1.307 * * *\end{array}$ \\
\hline $\begin{array}{c}\text { Place of residence } \\
\text { Urban (ref) } \\
\text { Rural }\end{array}$ & 1.029 & $1.073^{*}$ \\
\hline $\begin{array}{c}\text { Mother's Education } \\
\text { No education (ref) } \\
\text { Primary } \\
\text { Secondary } \\
\text { Higher }\end{array}$ & $\begin{array}{l}0.878 * * * \\
0.657 * * * \\
0.494 * * *\end{array}$ & $\begin{array}{c}0.951 \\
0.687 * * * \\
0.585^{* * *}\end{array}$ \\
\hline $\begin{array}{c}\text { Wealth Index } \\
\text { Very poor (ref) } \\
\text { Poor } \\
\text { Middle } \\
\text { Rich } \\
\text { Very rich } \\
\end{array}$ & $\begin{array}{c}1.084 \\
1.104^{* *} \\
1.045 \\
1.097\end{array}$ & $\begin{array}{c}0.958 \\
0.889 * \\
0.953 \\
0.797 * * *\end{array}$ \\
\hline $\begin{array}{l}\text { Ever use of contraception } \\
\text { Never used (ref) } \\
\text { Used only folkloric } \\
\text { Used traditional methods } \\
\text { Used modern method }\end{array}$ & $\begin{array}{l}2.397 * * * \\
1.507 * * * \\
1.514 * * *\end{array}$ & $\begin{array}{c}1.210 \\
1.688^{* * *} \\
1.772 * * *\end{array}$ \\
\hline $\begin{array}{l}\text { Mass media exposure } \\
\text { Not exposed (ref) } \\
\text { Less than once a week } \\
\text { At least once a week } \\
\text { Very often exposed }\end{array}$ & $\begin{array}{c}0.936 \\
0.874 * * * \\
0.820^{* * *}\end{array}$ & $\begin{array}{l}0.921 \\
0.979 \\
0.994\end{array}$ \\
\hline
\end{tabular}

Note: Reference category is denoted by (ref).

Significance: ${ }^{* * *} \mathrm{p}<0.01,{ }^{* *} \mathrm{p}<0.05,{ }^{*} \mathrm{p}<0.1$

Next, Hazards model have been applied to estimate the effects of women empowerment on parity transition. Out of three dimensions of women empowerment [16], only household decision-making autonomy showed significant relation with length of second birth interval, so hazards models are estimated only for household decision-making autonomy. Separate hazard models are estimated for different category of household decision-making autonomy for second birth interval, which are presented in Table 3. To explore the effect of household decisionmaking autonomy; basic demographic background such as the age at first marriage, the sex of the first-born, educational attainment, employment status, family 
planning methods and some other variables as well are controlled.

Early married (married before 20) not-empowered women are found to have largest second birth interval among all three groups, while moderately empowered and highly empowered mothers are found to have almost similar birth intervals (hazard ratios 0.935 and 0.943 respectively). However, mothers getting married later (after 25), are found to have largest birth interval among three groups. Empowered mothers are found to have 7.77 percent increased birth interval compare to reference group (married on or before 15), while for moderately empowered and not-empowered mothers this interval is shorter. Previous birth intervals have significant impact on birth interval for all of the three categories. Not empowered mothers are found to have largest second birth interval for all three categories.

Table 3. Hazards Models of the risk of second birth interval by household decision-making autonomy of mothers; BDHS-2007.

\begin{tabular}{|c|c|c|c|}
\hline Demographic and socio-economic characteristics & Not Empowered & Moderately Empowered & Empowered \\
\hline $\begin{array}{c}\text { Mother's age at first marriage } \\
\leq 15(\mathrm{ref}) \\
16-19 \\
20-24 \\
\geq 25 \\
\end{array}$ & $\begin{array}{c}0.765^{* * *} \\
0.755 \\
1.496\end{array}$ & $\begin{array}{l}0.935 \\
0.780 \\
1.497\end{array}$ & $\begin{array}{c}0.943 \\
0.795^{* * *} \\
0.923\end{array}$ \\
\hline $\begin{array}{l}\text { Gender of } \mathbf{1}^{\text {st }} \text { child } \\
\end{array}$ & 1.131 & $1.154^{* *}$ & 1.112 \\
\hline \multicolumn{4}{|l|}{$\begin{array}{c}\text { Male (ref) } \\
\text { Female } \\
\end{array}$} \\
\hline \multicolumn{4}{|l|}{ Previous birth interval } \\
\hline $\begin{array}{c}\leq 12(\mathrm{ref}) \\
13-24 \\
25-36 \\
\geq 37\end{array}$ & $\begin{array}{c}0.866 \\
0.812^{*} \\
0.698^{* * *}\end{array}$ & $\begin{array}{c}1.115 \\
1.004 \\
0.842 * *\end{array}$ & $\begin{array}{c}1.057 \\
1.053 \\
0.889 * *\end{array}$ \\
\hline \multicolumn{4}{|l|}{ Division } \\
\hline $\begin{array}{c}\text { Barishal (ref) } \\
\text { Chittagong } \\
\text { Dhaka } \\
\text { Khulna } \\
\text { Rajshahi } \\
\text { Sylhet } \\
\end{array}$ & $\begin{array}{c}1.464^{* * *} \\
1.039 \\
0.915 \\
1.058 \\
1.657^{* * *}\end{array}$ & $\begin{array}{c}1.326^{* * *} \\
1.006 \\
0.853 \\
0.834^{* *} \\
1.413^{* * *}\end{array}$ & $\begin{array}{l}1.215^{* * *} \\
1.044 \\
0.834^{* * *} \\
0.877^{* *} \\
1.556^{* * *}\end{array}$ \\
\hline \multicolumn{4}{|l|}{ Place of residence } \\
\hline $\begin{array}{c}\text { Urban (ref) } \\
\text { Rural } \\
\end{array}$ & 0.966 & 1.064 & 1.050 \\
\hline \multicolumn{4}{|l|}{ Mother's Education } \\
\hline $\begin{array}{c}\text { No education (ref) } \\
\text { Primary } \\
\text { Secondary } \\
\text { Higher } \\
\end{array}$ & $\begin{array}{c}0.947 \\
0.628^{* * *} \\
0.720\end{array}$ & $\begin{array}{c}0.860^{* *} \\
0.620^{* * *} \\
0.434^{* * *}\end{array}$ & $\begin{array}{c}0.957 \\
0.674^{* * *} \\
0.500^{* * *}\end{array}$ \\
\hline \multicolumn{4}{|l|}{ Wealth Index } \\
\hline $\begin{array}{l}\text { Very poor (ref) } \\
\text { Poor } \\
\text { Middle } \\
\text { Rich } \\
\text { Very rich } \\
\end{array}$ & $\begin{array}{l}0.978 \\
1.114 \\
0.879 \\
1.099\end{array}$ & $\begin{array}{l}1.092 \\
1.103 \\
1.073 \\
1.120\end{array}$ & $\begin{array}{l}1.017 \\
0.973 \\
1.029 \\
1.063\end{array}$ \\
\hline \multicolumn{4}{|l|}{ Employment } \\
\hline $\begin{array}{c}\text { Not employed (ref) } \\
\text { Employed }\end{array}$ & $0.996 * * *$ & 0.997 & $0.770^{* *}$ \\
\hline \multicolumn{4}{|l|}{ Ever use of contraception } \\
\hline $\begin{array}{c}\text { Never used (ref) } \\
\text { Used only folkloric } \\
\text { Used traditional methods }\end{array}$ & $\begin{array}{c}5.718^{*} \\
1.006\end{array}$ & $\begin{array}{c}1.094 \\
1.690^{* * *}\end{array}$ & $\begin{array}{l}2.169 * * \\
1.689 * * *\end{array}$ \\
\hline Used modern method & $1.246 * *$ & $1.364 * * *$ & $1.577^{* * *}$ \\
\hline \multicolumn{4}{|l|}{ Mass media exposure } \\
\hline $\begin{array}{l}\text { Not exposed (ref) } \\
\text { Less than once a week } \\
\text { At least once a week } \\
\text { Very often exposed }\end{array}$ & $\begin{array}{l}1.016 \\
0.893 \\
0.960\end{array}$ & $\begin{array}{l}1.005 \\
0.968\end{array}$ & $\begin{array}{c}0.931 \\
0.929 \\
0.842 * * *\end{array}$ \\
\hline
\end{tabular}

Note: Reference category is denoted by (ref).

Significance: ${ }^{* * *} \mathrm{p}<0.01,{ }^{* *} \mathrm{p}<0.05,{ }^{*} \mathrm{p}<0.1$

One of the major findings of the current study is, household decision-making autonomy cannot turn women to get rid of gender preference. Gender preference is significant for moderately empowered women, and all three categories of mothers have shorter birth interval if the first child was female (hazard ratios are 1.131, 1.154, and 1.112 respectively for not-empowered, moderately empowered and empowered mothers).

Regional impact is present for all three indicators of household decision-making autonomy in case of transition to second birth but place of residence does not have significant role on determining length of second birth interval. For Khulna division, second birth interval is larger for all three indicators. For less empowered women 8.5 percent, for moderately empowered women 14.7 percent and for highly empowered women 16.6 percent increased second birth interval is observed for Khulna Division. Birth intervals for place of residence differ very slightly, though no significant impact is found. Like the results obtained for employment status (Table 2), moderately empowered and empowered mothers are found to have slightly larger birth interval compared to notempowered mothers. Almost similar results were obtained in previous research [24]. Contraception status showed 
significant impact for all of the empowerment level, though birth intervals are found to be shorter in case of various method users compare to non-users. Lowest birth interval is observed for non-empowered, folkloric methods user mothers; while highest second birth interval is observed for not-empowered traditional method users. For modern method users, hazard ratios are 1.246, 1.364 and 1.577 respectively for non-empowered, moderately empowered and highly empowered women.

Expected result is obtained for mother's level of education, which is similar to previous studies $[6,16]$. With increase of education level, the duration of second birth intervals increase. For higher educated mothers, birth interval is 28 percent, 46.6 percent and 50 percent less than non-educated mother for non-empowered, moderately and highly empowered mothers. This signifies the impact of joint effect of empowerment and women's education stipulation for Bangladesh. Employment brings higher second birth interval for highly empowered mothers; they have 23 percent increased birth interval than unemployed mothers. Employment status has no significant impact in case of moderately empowered mothers. For women's educational level and employment status, similar results were obtained in previous study [20]. Mass media also plays a significant role for highly empowered mothers; with increase in level of mass media exposure the birth interval decrease for all three indicators. Very often exposed empowered mothers have 15.8 percent increased birth intervals than non-exposed mothers.

\section{Discussion}

The most common assumption about women's autonomy, education and employment is that; education leads to autonomy, which lets women stand up to their husbands and/or provides them a forum for them to learn about fertility control and make effective use of health care system [11]. Major agendas of millennium development goals were to reduce fertility levels and empowering women. As a result of continuous assessments, Bangladesh achieved notable success on both of these fields. This study tries to explore whether women's employment status and empowerment affects the fertility levels, in particular their transition to second parity.

There were two parts in this study. In first part, timing of second birth is explored from the notion of employment status while in second part it is explored from the level of empowerment. Employment level is found to be significant differential of fertility; two different models construct this fact. Previous birth experience and marital age of mother is significant determinant for second parity progression. Effect of gender preference is still present; for both unemployed and employed mothers, second birth interval is shorter if they have daughter as first child. The most interesting result is obtained for place of residence (urban/rural), employed mothers of rural reside have shorter birth interval compare to urban their counterparts. For employed mothers this result is kind of unusual, as it is well established that employed mother always seek for less number of child. One of the possible reasons may be relaxed job structure in rural areas, which accept mothers to have second parity in shorter duration and ability to take proper care. However, this assumption needs further investigation after controlling for other socio-economic relevant factors.

From three dimension of women empowerment, only household decision-making autonomy showed significant impact on timing of second parity. Therefore, in second part, hazard models are applied for all the three levels of household decision-making autonomy separately to compare and have a clear profile of household decisionmaking autonomy on second parity progression. The obtained results suggest; for few factors like mothers education level, employment status and mass media exposure status; the parity transition time varied between non-empowered, moderately empowered and highly empowered mothers. One major findings of the current study is household decision-making autonomy cannot turn women to get rid of gender preference. Gender preference showed significant impact in second birth interval for moderately empowered women, and all three categories of mothers have shorter birth interval if the first child was female.

The major outcome of this study showed that there is strong inverse relationship between empowerment and fertility. The relationship between women empowerment and contraceptive use was positively associated. Women's education is significant determinant of second parity transition, even after controlling for other variables. Decline of second-order fertility is observed among women who have completed secondary education or higher. The analysis, however, has demonstrated that within the framework of the ongoing process of empowerment level, even the highly empowered groups of women showed a slight change in second-birth intensity compare to that of non-empowered mothers. Thus, because women who had no schooling, who lived in rural areas and who had no work experience still represent a sizable proportion of the Bangladeshi population, we can expect a further decline in the number of large families in the near future.

For a developing country like Bangladesh, the percentage of employed women is still not in a notable condition. According to BDHS 2007, only 32.7 percentage women are involved in various income generating activities. Participation to labor force is important both for country and family, as it facilitates to have experiences from others about family norms and public health related issues. It should be noted that women's education and employment are positively related, so job sector is needed to reform for women both in government and private sector; else women will not have interest to be higher educated when there is no appropriate jobs available for them.

As to the aggregate level of fertility, decreasing fertility will continue, if only because of the continuing trend towards greater education, empowerment level, and labor force participation among women. Still steps are needed to be taken to improve scenario in women empowerment level. The factors like improvements in women mobility outside home, access to health and family planning services and educational opportunities may play a vital role in this situation. Future research should focus on the social interactions among empowered women and their potential for bringing about large-scale social change 
which can promote the benefit of small family norm to the rest of the society.

\section{References}

[1] National Institute of Population Research and Training, Bangladesh Demographic and Health Survey 2007, Dhaka: National Institute of Population Research and Training, 2009.

[2] Vignoli, D., "Fertility change in Egypt: From Second to Third Birth”, Demographic Research, 15. 499-516. 2006.

[3] Rao, K.V. and Balakrishnan, T.R., "Timing of first Birth and second birth spacing in Canada”, Journal of Biosocial Science, 21. 293-300. 1989.

[4] Nath, D.C., Land, K.C., Singh, K.K. and Talukdar, P.K., "Most recent birth intervals in a traditional society: A Life Table and Hazard Regression analysis”, Canadian Study in Population, 21 (2). 149-64. 1994.

[5] Sayem, A.M. and Sanaullah, N., "Examination of birth intervals: Marriage to first, first to second and mean birth Intervals in Bangladeshi women”, Asia Pacific Social Science Review, 21 (2). 1-18. 2011.

[6] Adsera, A., "The interplay of employment uncertainty and education in explaining second births in Europe”, Demographic Research, 25. 513-44. 2011.

[7] Kravdal, O., "The high fertility of college educated women in Norway”, Demographic Research, 5. 187-216. 2001.

[8] Galor, O. and Weil, D., “The gender gap, fertility and growth”, American Economic Review, 86. 374-87. 1996.

[9] Islam, M.M., Dorvlo, A., Al-Qasmi, A.M., "Proximate determinants of declining fertility in Oman in the 1990s", Canadian Studies in Population, 38 (3-4), 133-52. 2011.

[10] Nikkah, A.H., Redzuan, M. and Samah, A.A., "The effect of women's socio-demographic variables on their empowerment”, Journal of American Science, 6 (11). 426-34. 2010.

[11] Mason, K.O., "The impact of women's social position on fertility in developing countries”, Sociological Forum, 4. 718-45. 1987.

[12] Dyson, T. and Moore, M., "On kinship structure, female autonomy, and demographic behavior in India”, Population and Development Review, 9 (1). 35-60. 1983.
[13] Gwako, E.L., "Conjugal power in rural Kenya families: It's influence on women's decisions about family size and family planning practices”, Sex Roles, 36 (3-4). 127-47. 1997.

[14] Morgan, P.S. and Niraula, B.B. "Gender inequality and fertility in two Nepali villages”, Population and Development Review, 21 (3). 541-61. 1995.

[15] Schuler, S.R., Hashemi, A.M. and Riley, A.P., "The influence of changing roles and status in Bangladesh's fertility transition: Evidence from a study of credit programs and contraceptive use”, World Development, 25 (4). 563-75. 1997.

[16] Woldemicael, G., "Women's autonomy and reproductive preferences in Eritrea”, Journal of Biosocial Science, 41 (2). 16181. 2009.

[17] Balk, D., "Individual and community aspects of women's status and fertility in rural Bangladesh”, Population Studies, 48 (1). 2145. 1994.

[18] Hindin, M.J.,"Women's autonomy, women's status and fertilityrelated behavior in Zimbabwe”, Population Research and Policy Review, 19. 255-82. 2000.

[19] Upadhyay, U.D. and Hindin, M.J., "Do higher status and more autonomous women have longer birth intervals? Results from Cebu, Philippines”, Social Science \& Medicine, 60 (11). 2641-55. 2005.

[20] Abbasi, S.R.S., Zafar, M.I., Aslam, M. and Batool, Z., "Effect of female financial empowerment on contraceptive and fertility behavior: Woman control on household expenditure”, Pakistan Journal of Agricultural Science, 45 (3). 112-18. 2008.

[21] Larsen, U. and Hollos, M., "Women's empowerment and fertility decline among the pare of Kilimanjaro region, Northern Tanzania”, Social Science and Medicine, 57 (6). 1099-115. 2003.

[22] Bairagi, R., "Effects of sex preference on contraceptive use, abortion and fertility in Matlab, Bangladesh”, International Family Planning Perspective, 27 (3). 137-43. 2001.

[23] Kamal, N., Saha, U.R., Khan, A.M. and Bairagi, R., "Use of periodic abstinence in Bangladesh: Do they really understand?”, Journal of Biosocial Science, 39. 27-40. 2007.

[24] Ahmed, T., Perveen, S., "Factors affecting fertility transition at District Level". Proceedings of the in Pakistan's Population Stabilization Prospects: Conference, Population Association of Pakistan, Islamabad, 3-29. 2001. 